\title{
SPATIAL 3D DOCUMENTATION OF HISTORICAL MINING REMNANTS IN FORESTED AREA IN THE ERZGEBIRGE/KRUŠNOHOŘÍ MINING REGION UNESCO SITE
}

\author{
Karel Pavelka a (D), Eva Matoušková a , Karel Pavelka jr. ${ }^{\text {a (iD), Jan Pacina }}{ }^{\text {a,b }}$ \\ a Department of Geomatics / Czech Technical University in Prague, Faculty of Civil Engineering, Thakurova 7, Prague 6, 16629, \\ Czech Republic.pavelka@fsv.cvut.cz, matoueva@gmail.com, karel.pavelka@hotmail.com \\ bJan Evangelista Purkyně University in Ústí nad Labem, Faculty of Environment, Pasteurova 3632/15, 40096 Ústí nad Labem, \\ Czech Republic, jan.pacina@ujep.cz
}

KEY WORDS: Virtual archaeology, Digital archaeology, Laser scanning, Cultural heritage, Documentation, 3D reconstruction, Historical mining

\begin{abstract}
:
This contribution deals in the possibilities of 3D documentation of historical mining relicts hidden in the forest. On the Czech German border, in the Ore Mountains, several historical mining relicts are located there. There are interesting underground spaces (historical mines), some of which have recently been made available for visits by tourists. But there are many relicts on the surface that are linked to mining and are not known or on the fringes of interest. These are mining pits, dumps, water works, remains of buildings and historic entrance roads. Many of them are in forest areas, were not documented or archaeologically explored, and have recently been devastated by amateur collectors equipped with metal detectors who unfortunately destroy unexplored localities to find interesting relicts. For the basic documentation and delimitation of these objects, aerial laser scanning (ALS) and personal laser mobile scanning (PLS) were used; some finds were documented by close-range photogrammetry.
\end{abstract}

\section{INTRODUCTION}

Monument care is often on the fringes of interest in lesserknown historical mining cultural monuments. Well-known sightseeing historical mines are especially maintained. They are nowadays very popular. It is different regarding surface relicts. In many cases, both historical underground and surface objects are discovered, destroyed, and constantly changed over time. Over hundreds of years, the surface relicts of mining activity changed and were forgotten. The inhabited border areas in the Czech Republic were originally deforested until the middle Ages, then forested, mainly after WW II, after the expulsion of the Sudeten Germans who lived there. German miners brought knowledge about the mining of minerals, especially tin and silver in the Ore Mountains. It is logical that the oldest mining university (now TU Bergakademie Freiberg) was founded in 1765 in nearby Saxony, in the town of Freiberg. After the political changes at the beginning of the 1990s, the public slowly began to show interest in historical mining activities and the so-called Montanists gradually developed in both the tourist and professional fields.

Only recently have historical mining sites become interesting for the public, thanks to the efforts of the state administration and civic associations, which have often made a significant contribution to the preservation of these monuments. Long-term efforts to include historical mining activities in the Ore Mountains on the UNESCO list of monuments certainly contributed to the popularization. This was achieved in the spring of 2019. Unfortunately, the popularization of mining historical activities, the release of accurate maps and especially the digital relief model of the Czech Republic from aerial laser scanning, and the free sale of metal detectors brought completely negative examples of cultural heritage destruction. Most of the objects of historical mining activity in the Czech Republic are in mountain areas, which are now forest areas. An uncontrollable number of "amateur archaeologists", owners of metal detectors and mineral collectors in the last decade have greatly ravaged the hitherto undiscovered and unknown small monuments, including historical mining activities. Lack of legislation, lack of interest, and weakness of the state administration enable the long-term destruction of cultural heritage (Malina,2015).

\section{CASE STUDY: ORE MOUNTAINS}

The Ore Mountains have been inhabited since the twelfth century precisely because of significant ore deposits. The greatest expansion came in the sixteenth century with the discovery of rich silver ores around the town of Jáchymov. In 1516, the owner of the estate, Count Stephen von Schlick (Štěpán Šlik), decided to establish a town on the site of the Konradsgrün settlement. The settlement was in a deep valley and from there it got a new town (the name in German was Thal), and a little later the town was re-named after St. Jáchym (German St. Joachims-thal, now known in Czech as Jáchymov). The town was already promoted to a free mining town by King Louis II of Hungary (King of Hungary, Croatia, and Bohemia) in 1520 . With the discovery of silver, silver fever literally broke 
out, and silver attracted a number of prospectors and miners not only from Bohemia but also from Saxony, Tyrol, and the Rhineland. The population grew rapidly, and in 1534 Jáchymov already had over 18,000 inhabitants and for a short time was the second most populous city in Bohemia after Prague. Silver coins - tolars (the name of the coin after the original name of the town Thal) also began to be minted in Jáchymov. The coins began to be called thaler - tolar, and this name was the source of the name for the currency known as dollar. After the boom in silver mining in South America, the importance of Jáchymov declined and the second wave came with the discovery of uranium ores at the end of the nineteenth century. In the uranium ores of 1898, Marie and Pierre Curie discovered the chemical elements polonium and radium. Uranium became a strategic raw material after World War II. Unfortunately, this has brought several negative phenomena. The entire territory was militarily guarded during the Communist regime in the formerly Czechoslovakia. Uranium was mined mainly by political prisoners under inhumane conditions, and the ore was transported to the former Soviet Union. Mining was terminated in the 1960s, and many relicts remained (Jachymov, 2020).

\subsection{Abertamy - Boží Dar - Horní Blatná - Mining Landscape}

One of the Erzgebirge/Krušnohoří Mining Region UNESCO sites is the "Abertamy - Boží Dar - Horní Blatná" - Mining Landscape part (UNESCO, 2020). These three small cities are located near the Czech-German border and have a dramatical history based on the historical mining of silver, tin and other raw material and newly on uranium mining. In the forest and also on the plains around Boží Dar, you can find a large number of remnants of historical 3. Data acquirement - spatial 3D documentation of mining remnants in forested area mining, especially tin. Ore veins near the surface were mined using vertical or inclined pits. The reason was that there were unfavourable conditions for conventional mining with horizontal galleries, as the site is located on slightly sloping terrain. This technique was used in the 16th century in the cadastre of nearby Jáchymov (Derner, Hrubý, Malina, Večeřa, 2019).

\section{DATA ACQUIREMENT - SPATIAL 3D DOCUMENTATION OF MINING REMNANTS IN FORESTED AREA}

In terms of 3D documentation, laser scanning, aerial photogrammetry, and drone photogrammetry (Šedina, Housarová, Raeva, 2019, Pacina, Sládek, 2015) can be used, as well as close-range photogrammetry for small parts , in the form of IBMR (Image Based Modeling and Rendering, often called also as SfM - Structure from Motion). (Pavelka, Řezníček, Bílá \& Prunarová, 2013). Here we will deal only with the possibilities of the documentation of surface relicts of historical mining (Housarová, Šedina, Raeva, 2017). Laser scanning of various types were used (Housarová, Šedina, Pavelka, 2019).

Terrestrial laser scanners (TLS) are, in cultural heritage, currently quite common. Since 2000, they are basic instruments for precise 3D documentation. There are typically three types of laser scanners: ToF (time of flight) scanners for long distances measurement, phase laser scanners for shorter distances but with better resolution, triangular scanners for very short distances, and newly personal mobile scanners which can be conveniently used for fast spatial documentation. They are often used for data transfer to BIM (Doneus, Neubauer, 2005).
Another type is aerial laser scanning (ALS). This allows the creation of a detailed and accurate digital relief model (DRM) as well as a digital surface model (DSM). Because fullwaveform laser scanners are used, a DSM can be easily created from the first echo and a DRM from the last echo; it means the vegetation filtration in forested areas is relatively easy (Doneus, Briese, 2015, Faltýnová, Pavelka, 2011, Gojda, 2011).

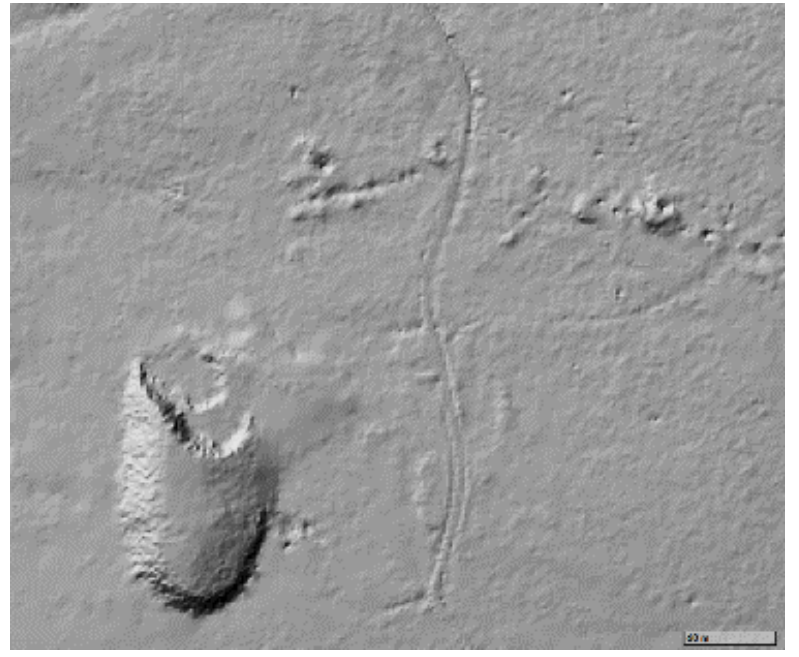

Figure 1. The DRM of Eastern part of Abertamy mining region; ALS, Czech Geodetic and Cadastral Office. The historical remnants are quite visible (in the upper part of the image), such as the nearby big deposit from Uranium mining (bottom left the big deposit)

In the Czech Republic, ALS of the entire area was performed in 2009-2013. The data has been officially published and is freely available. This resulted in the discovery of many archaeologically new sites in the Czech Republic and the better visibility or analysis of already known sites. ALS data is now commonly used in archeology and for the search of historical mining works or their remains (Fig.1). The density of points in this government project is 1-2 points per one square meter. This is good for mapping in terms of elevation and also for locating some archaeological artifacts, especially in forest stands, which hid and still hide many valuable remains. This is a significant help in finding the context and documenting historical mining activities. ALS has the advantage that the laser beam partially passes through the forest (Urban et al, 2020). The Ore Mountains are largely overgrown with Norway spruce. When scanning, it passes approximately $10 \%$ to the surface. Even so, it is enough to generate a high-quality digital relief model (DRM).

However, in some cases, this is not enough, and a new measurement or other technology needs to be used. Terrestrial laser scanning (TLS) in the forest is very problematic, slow, and often ineffective due to stand density. For this reason, a new ALS was carried out experimentally in the spring of 2020 for a small area using low-cost ALS system on an ultralight airplane (in collaboration with a project on Jan Evangelista Purkyně University in Ústí nad Labem, Czech Republic).

The quality of the data is not ideal, but with point density it is much better with approximately 20 points on one square meter Gojda, 2002, Gonizzi, Remondino, Visintini, 2012). 


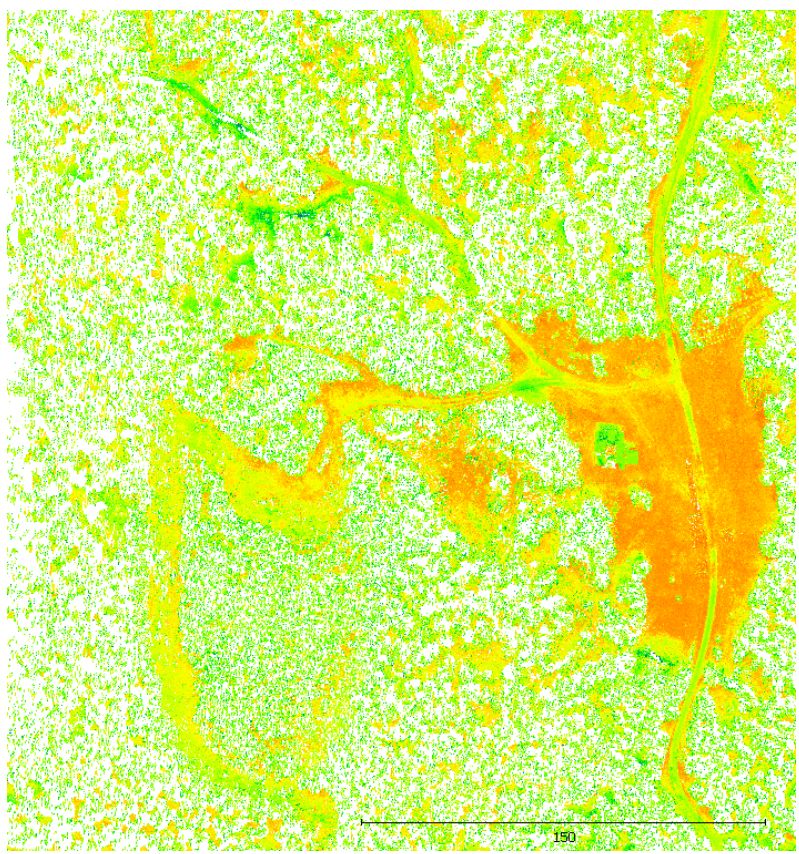

Figure 2. Low-cost ALS data, Eastern Abertamy mining site, point cloud density

The aerial measurement takes approximately 10 minutes and produces $400 \mathrm{MB}$ of data (resulted point cloud was directly a DRM, without vegetation).

It is interesting that directly behind the remnants from maybe the sixteenth seventeenth century (tin mining) there was a large uranium mine from the fifties of the last century (East Abertamy mining site) (Fig.2-5).

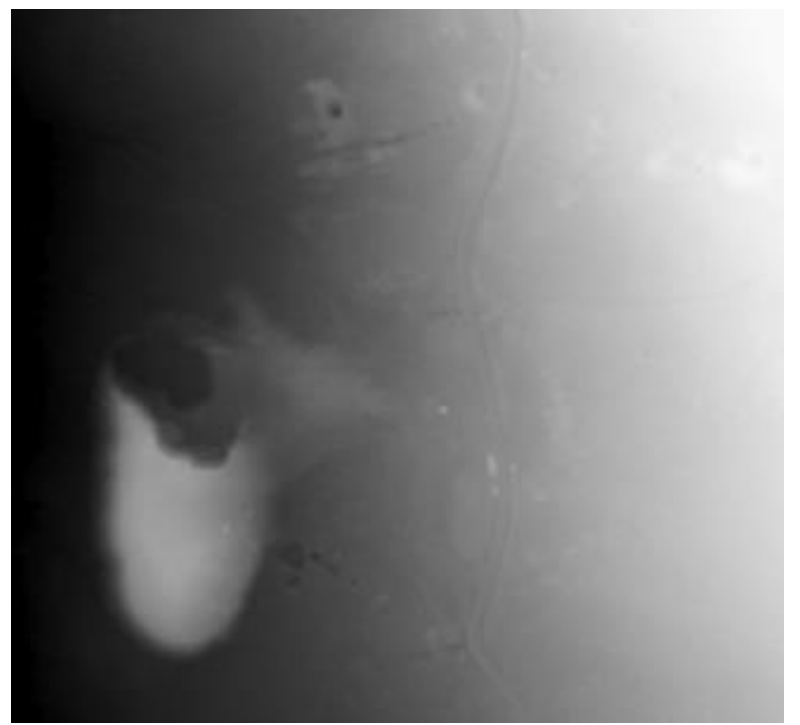

Figure 3. Generated DRM from low-cost ALS (Eastern Abertamy)

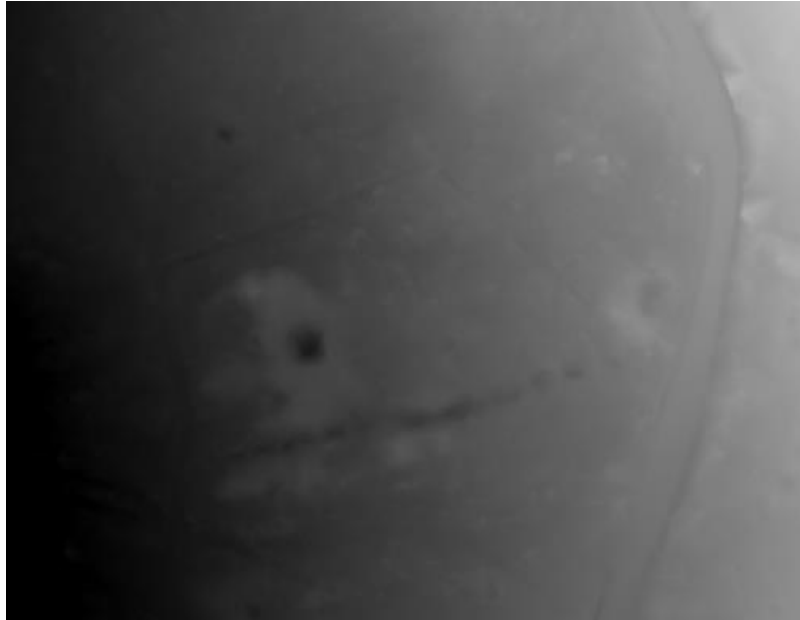

Figure 4. The DRM of Eastern part of Abertamy mining region; low-cost ALS, historical mining activity

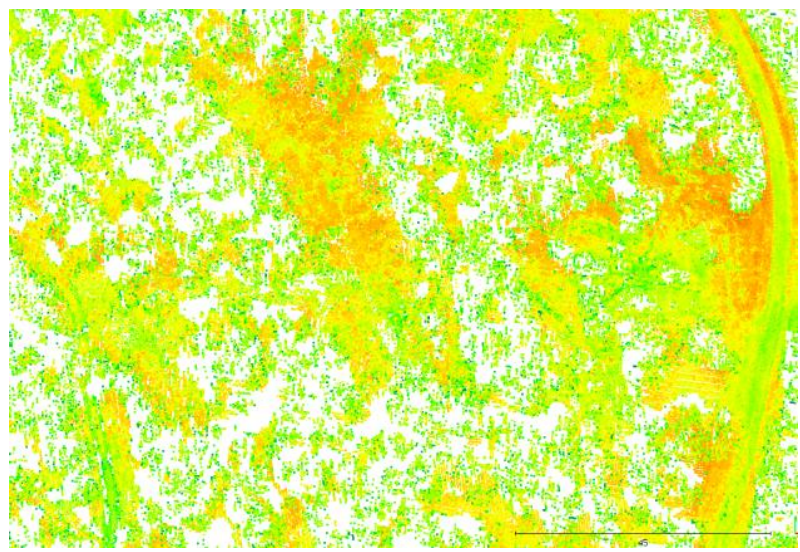

Figure 5. The point cloud density; Eastern part of Abertamy mining region; low-cost ALS, historical mining activity

Remains of mining activity can be clearly seen from above. In many cases, however, ground reconnaissance is much more important. Therefore, a personal mobile laser scanner (PLS) ZEB-REVO was used (Fig.6-7, 10-11). It is easy to use, light to transport and carry, and does not create unnecessarily large data files as by TLS. The measurement takes dozens of minutes only for one hectare (depending on measured structures and forest density). In our case, it was 40 minutes, $150 \mathrm{MB}$ of data (was necessary to filter the resulting point cloud due to dense forest vegetation)

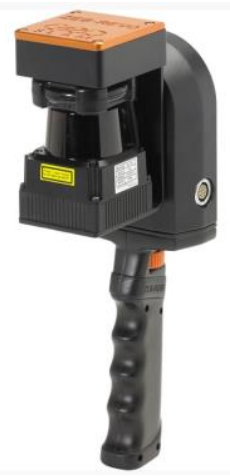

Figure 6. The ZEB-REVO personal mobile laser scanner, handheld device 
Unfortunately, during the measurement, a place was found where someone very destructively destroyed a valuable finding site while searching with a metal detector. Since he was only looking for metal objects, he was not interested in the ceramic remains.

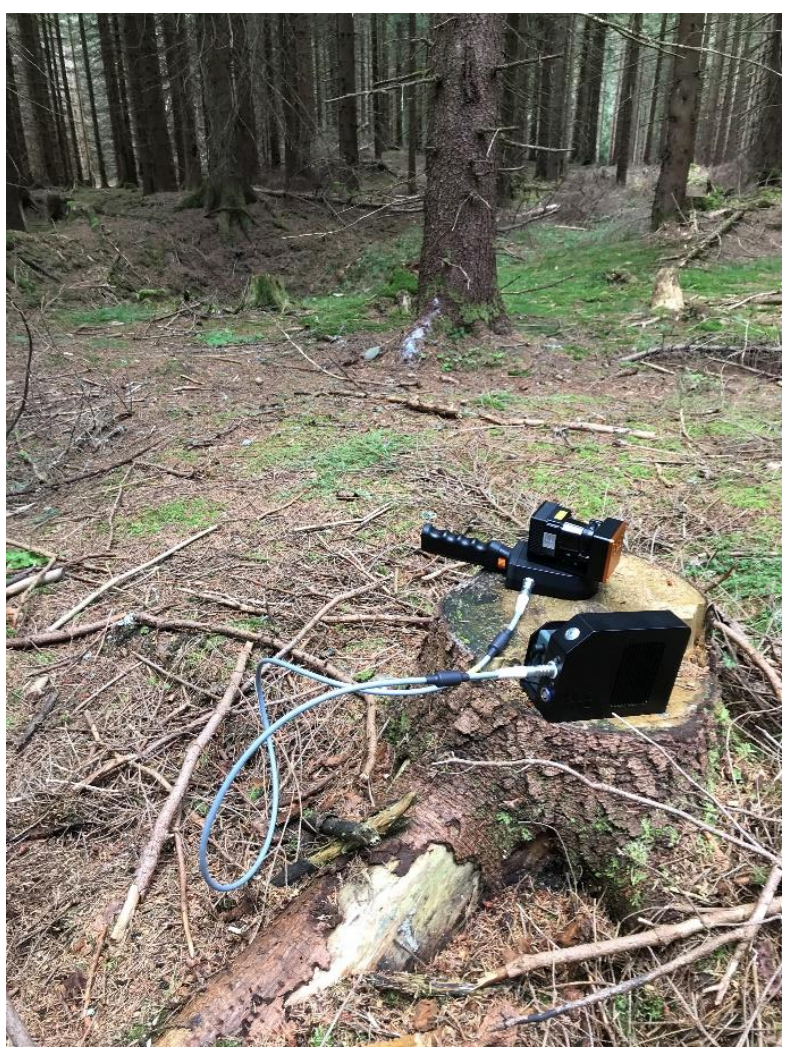

Figure 7. The ZEB-REVO personal mobile laser scanner with cable, battery, and integrated data storage

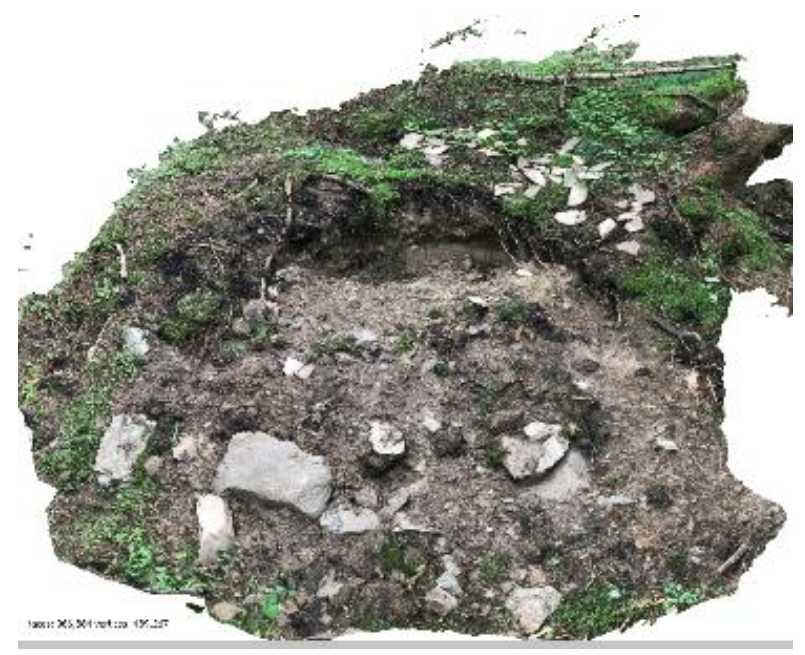

Figure 8. Looted archaeological dig, the 3D model, Metashape software; 25 photographs taken by a common iPhone camera

The place was simply photogrammetrically documented by a mobile phone camera, then the remains were secured, and the place was backfilled (Fig.8-9). Unfortunately, this type of archaeological digs looting happens often today. A number of ceramic shards were found on the site include metals relicts (Fig.12). Depending on their shape and design, these can be dated to the middle of the sixteenth to the beginning of the seventeenth century (Malina, 2015).

A more detailed elaboration of the findings will be carried out next year.

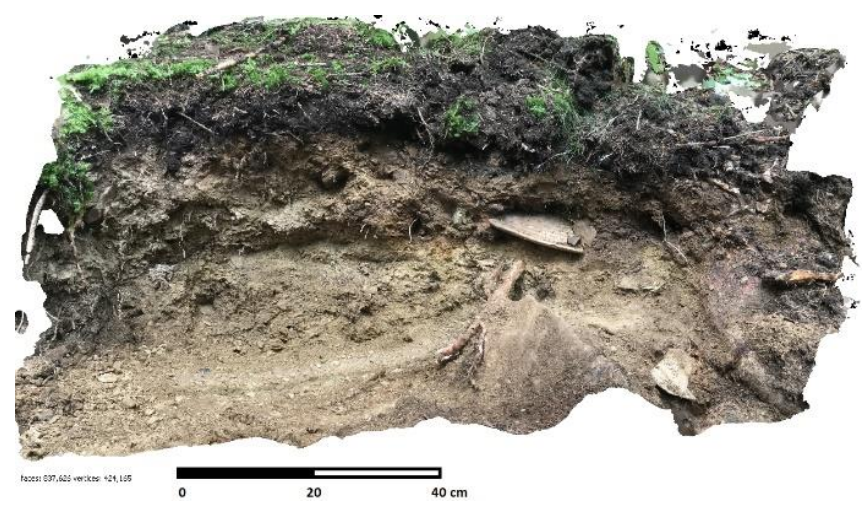

Figure 9. Looted archaeological dig, detail

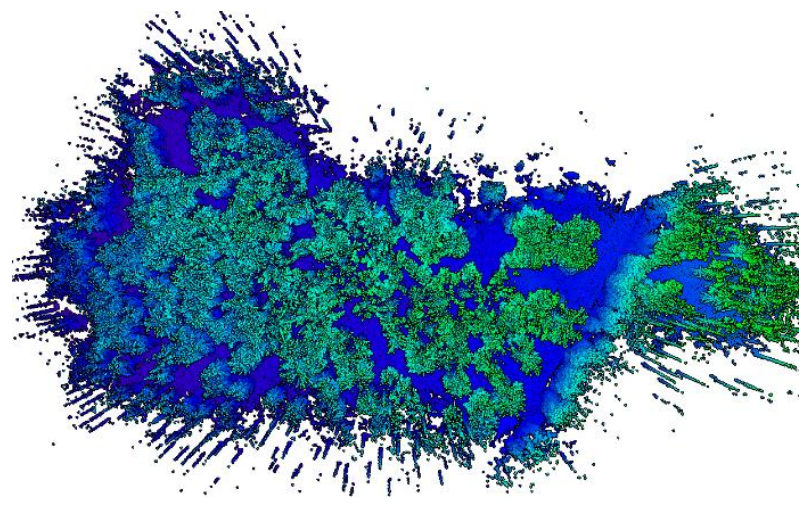

Figure 10. The measurement was made using the ZEB-REVO personal mobile laser scanner

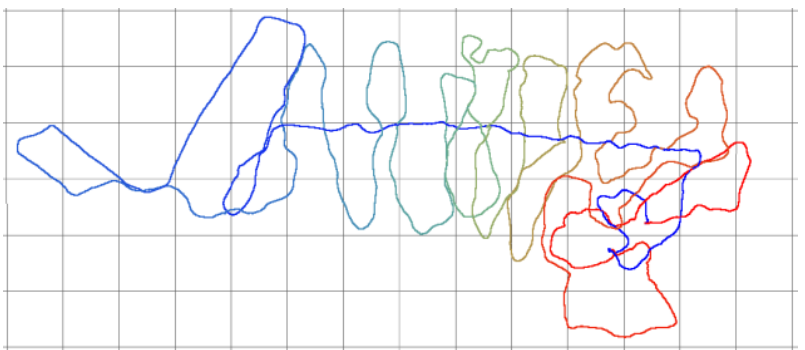

Figure 11. Measurement trajectory 


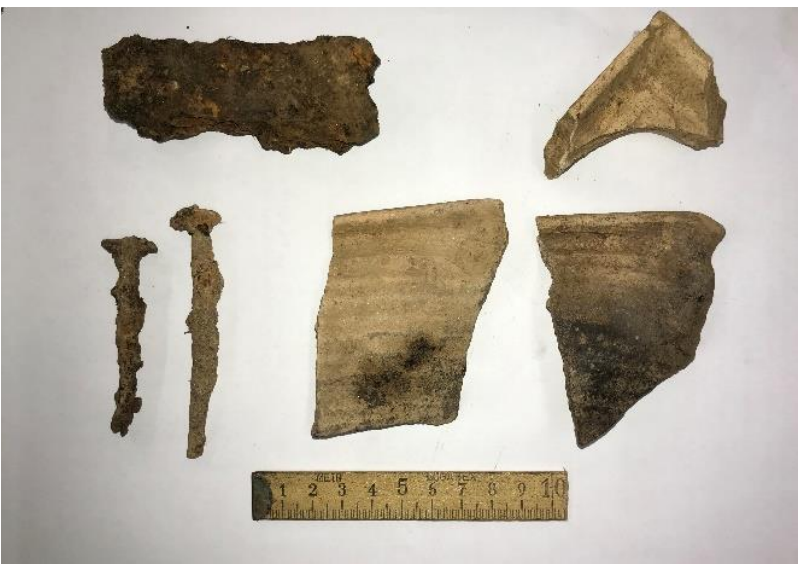

Figure 12. Examples of finds from the looted site: ceramic shard, nails, and a fraction of a mining hammer. Based on

(Malina,2015) these artifacts can be dated to the sixteenth seventeenth century.

\section{METHODOLOGY}

As it was written, several technologies were used. In general, photogrammetry and laser scanning of various types produce a point cloud that is further processed. Because multiple data types were obtained from a single site, they were compared in CloudCompare software to detect differences. Point clouds from a forested site were cleaned by removing vegetation using data filtering (Fig.13).

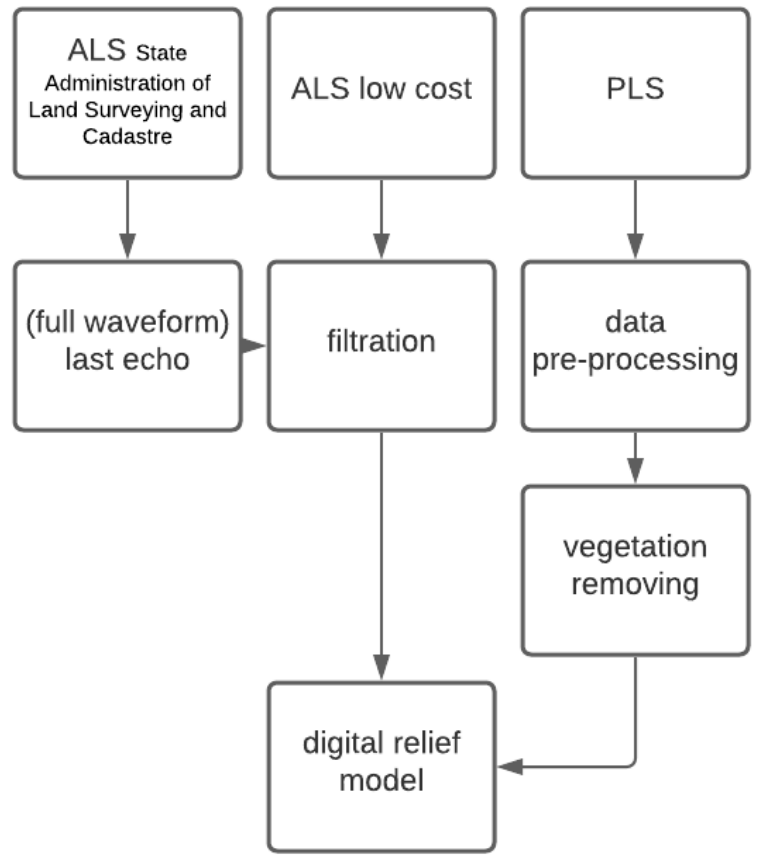

Figure 13. Data processing flowchart

\section{VEGETATION REMOVING}

The ZEB-REV PLS such as other terrestrial laser scanners or similar systems creates a point cloud, which is in this case necessary to filter for removing forest vegetation. There are many possibilities how it can do it.

CloudCompare software is very popular. It allows the filtering of point clouds in many ways. There are two main options in CloudCompare. The easier one is to use the CSF plugin; it works intuitively and automatically. Another option is to use, for example, DTmaster from Trimble INPHO. It edited DMR 5G from ALS for the whole Czech Republic. It also has tools and filters for automatic classification.

In our case, we used a script in MATLAB, which removes vegetation from TLS data successfully (forest stand). The VegRem script can be used for small areas captured by TLS. It was used by the CTU in Prague, FCE, dept. of Geomatics in archaeological analysis of military remnants from the Thirty years war, which are usually in forested areas (remnants of artillery redoubts and trenches) (Fig.14-16).

The script works on a relatively simple principle. An area where vegetation is to be removed must first be trimmed to a level of several meters above the ground. Furthermore, the size of the filter is defined by a floating window, e.g. $10 \times 10 \mathrm{~cm}$, which contains detailed points generated by any technology (laser scanning or photogrammetrically). Next, the point with the smallest height is searched for and it is placed in the middle of the search window. The process is repeated. The program creates a new cloud in *.vtx format (text file). The script runs in the MATLAB environment. The input point cloud is in *.vtx format and can be exported from Geomagic Wrap software or created. When creating a point cloud, the first two lines are the header of the file. The next lines are the coordinates of the point cloud in the shape of $\mathrm{X}, \mathrm{Y}$ and $\mathrm{Z}$. The VegRem script is simple and is available on the CTU FCE photogrammetry laboratory server.

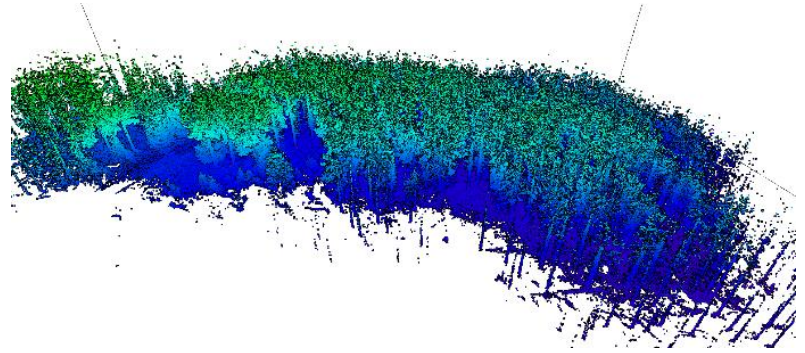

Figure 14. ZEB-REVO PLS measurement before forest vegetation filtering (historical mining area)

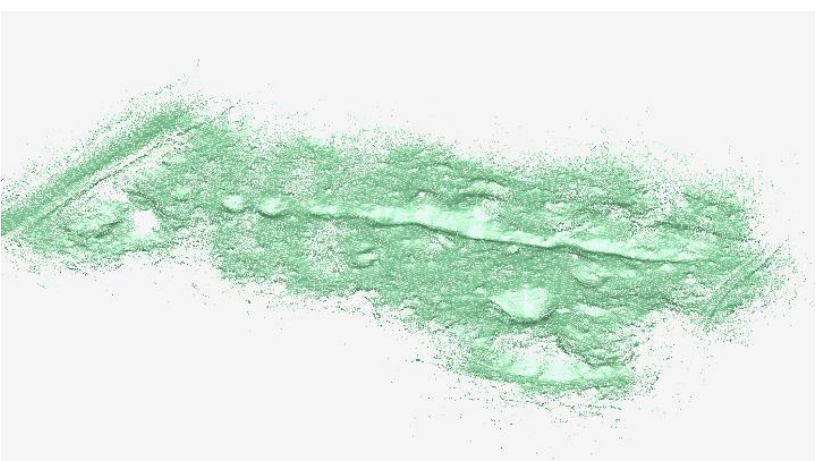

Figure 15. ZEB-REVO measurement after forest vegetation filtering (historical mining area) 


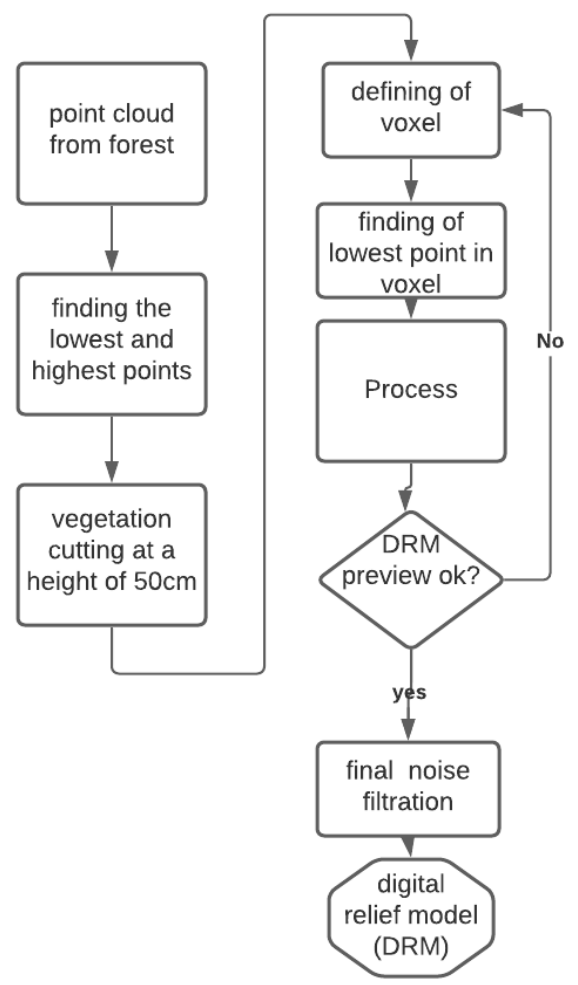

Figure 16. VegRem flowchart

\section{URANIUM PERIOD}

As already written, the last historical mining in the Jáchymov region was the mining of uranium ore. Many mining objects and buildings or their remains have been preserved from the times of uranium mining. Unfortunately, these are often the remnants of concentration camps where political prisoners were interned after the communist coup. This history is part of the grant research at the University of West Bohemia in Pilsen (Vařeka,2020).

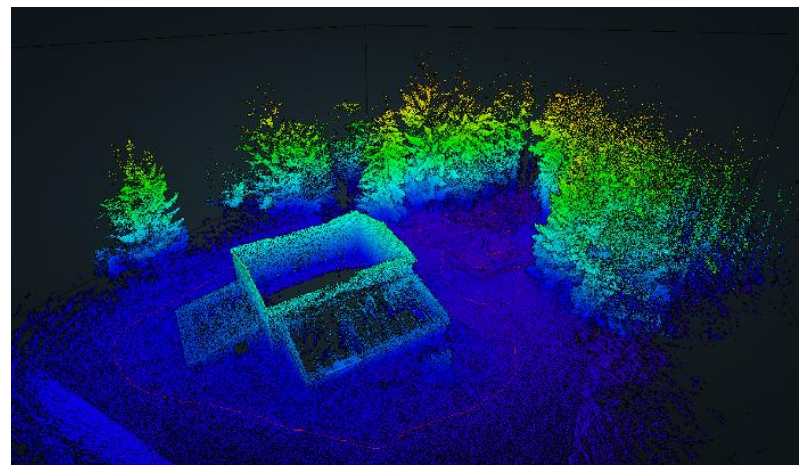

Figure 17. Nearby historical mining relicts from sixteenthseventeenth century, an abandoned relict on Uranium mining can be found (ZEB-REVO PLS)

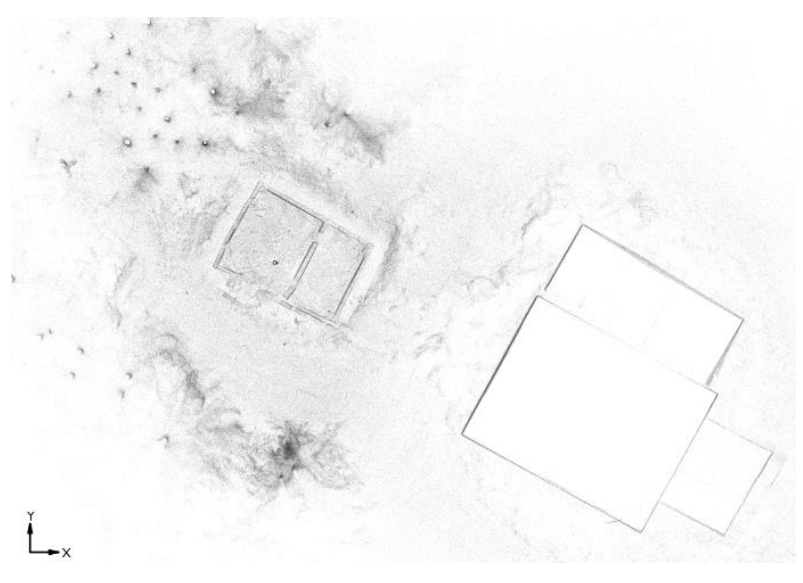

Figure 18 Using the "Draw" module in the GeoSlam HUB software an orthographic view on the captured data can be done

On figure 18. and 19 remaining remnants of concrete foundations of a buried mining pit have very good visibility. At right there is the dilapidated structure of the engine room of the mining tower (Fig.16-19).

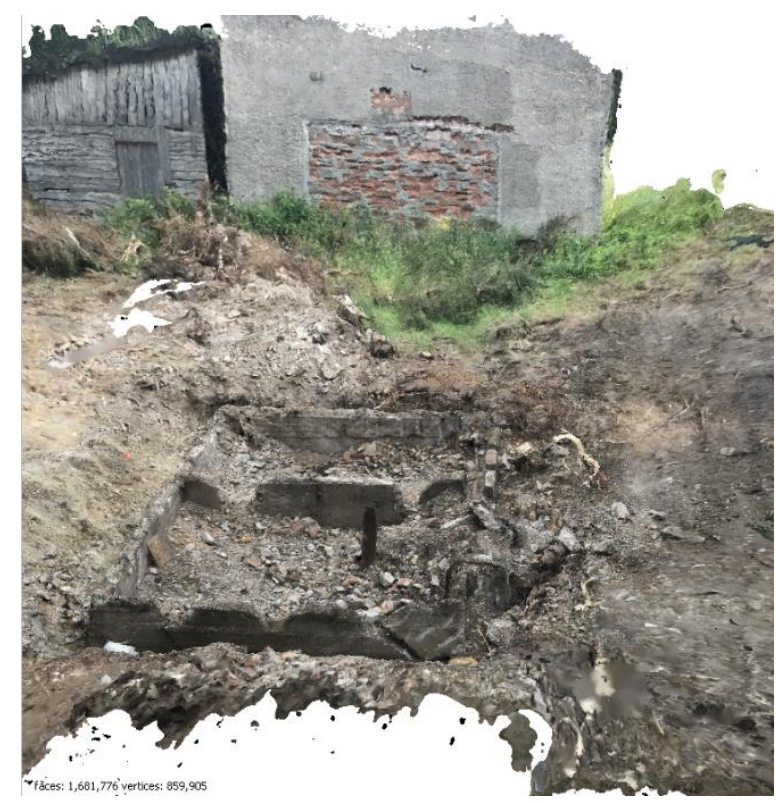

Figure 19. Using modern cameras mounted in smartphones, simple documentation 3D models can be easily made using modern software (buried mining pit from Uranium period)

\section{CONCLUSION}

As was shown, several technologies were used for documentation of a historical mining area. Based on professional outputs, the digital relief model DMR5G, in shaded form, created by the Czech Geodetic and Cadastral Office, is very good for localization of these objects generally and free of charge. The low-cost ALS system mounted on an ultralight airplane can be used too; it gives better point density on open areas (as shown on Figure 2). However, in forested areas it depends highly on terrain and forest conditions; many points on small areas are missing. The penetration of this type ALS is not so good as when using professional systems focused on large areas. It can be a good alternative for detailed DRM on smaller 
open areas, which can be perfect for archaeological excavations or for the detection of terrain signatures of underground objects. A very good solution for the aim of this small project seems to be the ZEB-REVO PLS. It is really easily transportable, easy to operate and produces reasonably large amounts of data. In this case, it does not matter that this type is not equipped with a camera. These are terrain relicts only. The automatic closerange photogrammetry can be used as a supporting technology, which can be used for fast and inexpensive 3D documentation of small objects or finds. The use of PLS will certainly have a future and a rapid development and based on IMU and SLAM technology.

\section{ACKNOWLEDGEMENTS}

'This work was supported by the [internal grant of the Czech Technical University in Prague] under Grant [number SGS21/054/OHK1/1T/11].

\section{REFERENCES}

Derner, K., Hrubý, P. Malina, O., Večeřa, J., 2019. Hornické revíry vrcholného středověku a raného novověku ve srovnávacím pohledu - Mining regions in the high Middle Ages and the early modern age viewed in terms of comparison, Archaeologia Historica 44/2.

Doneus, M., Neubauer, W., 2005. 3D laser scanners on archaeological excavations. Conference: XXth International Symposium CIPA, Torino 2005At: Torino, Italy. Volume: The International Archives of Photogrammetry, Remote Sensing and Spatial Information Sciences, Vol. -5/C34/1, 470-475226-231

Doneus, M., Briese, Ch., 2015. Full-waveform airborne laser scanning as a tool for archaeological reconnaissance. From Space to Place. Proceedings of the 2nd International Conference on Remote Sensing in Archaeology. BAR International Series 1568 Publisher: Archeopress, Editors: Campana S., Forte M.

Faltýnová, M., Pavelka, K., 2011. Aerial Laser Scanning in Archeology. December 2011. Geoinformatics FCE CTU, 6. 10.14311/gi.6.14

Gojda, M., 2002. Aerial Archaeology in Bohemia at the turn of the twenty first century: integration of landscape studies and non-destructive archaeology. Aerial archaeology. Developing future practice (Bewley, B. - Raczkowski, W. eds.), 68-75. Amsterdam-Berlin-Oxford-Tokyo-Washington D. C.: IOS Press.

Gojda, M., 2011. Archaeology in current society. A central European perspective, Antiquity 85, 1448-53. Doi:10.1017/S0003598X00062177

Gonizzi B.S., Remondino, F., Visintini, D., 2012. Photogrammetry and laser scanning for archaeological site 3D modeling - Some critical issues. CEUR Workshop Proceedings. 948. B1-B10.

Housarová, E; Šedina, J., Pavelka, K., 2019. Study of Erbil AlQala citadel time changes by comparison of historical and contemporary image data. European Journal of Remote Sensing. 2019, 52(1), 202-208. ISSN 2279-7254. Doi:10.1080/22797254.2018.1531683
Housarová, E. Šedina, J., Raeva, P., 2017. Photogrammetric IBMR Technology and Laser Scanning in Cultural Heritage Documentation. 17th International Multidisciplinary Scientific Geoconference, Conference Proceedings Volume 17, Informatics, Geoinformatics and Remote Sensing Issue 22, Geodesy and Mine Surveying. Sofia: International Multidisciplinary Scientific GeoConference SGEM, 2017. p. 187-194. vol. 17. ISSN 1314-2704. ISBN 978-619-7408-02-7. Doi:10.5593/sgem2017/23/S10.041

Jáchymov. 2020. History. (3 November 2020), https://www.mestojachymov.cz/historie/d-1026

Malina, O., 2015. Poznámky k hornické krajině jáchymovského revíru (in Czech), Archeologie západnich Čech 11-15. Plzeň, Czech Republic.

Pacina, J., Sládek, J., 2015. Observing Landscape Changes Using Distant Methods. Civil Engineering Journal. 24. Doi: 10.14311/CEJ.2015.01.0004

Pavelka, K., Řezníček, J., Bílá, Z., Prunarová, L., 2013. NonExpensive 3D Documentation and Modelling of Historical Object and Archaeological Artefacts by Using Close Range Photogrammetry, Geoinformatics FCE CTU, 2013(10), 53-66. ISSN 1802-2669. 10.14311/gi.10.5

Šedina, J. Housarová, E., Raeva, P., 2019. Using RPAS for the detection of archaeological objects using multispectral and thermal imaging European Journal of Remote Sensing. 2019, 52(sup1), $182-191 . \quad$ ISSN $2279-7254$. Doi:10.1080/22797254.2018.1562848

UNESCO. 2020. Erzgebirge/Krušnohoří Mining Region. (20 January 2021), https://whc.unesco.org/en/list/1478/

Urban, R., Štroner, M., Blišt’an, P., Kovanič, L., Pukanská, K., Bartoš, K., Blišt'anová, M., 2020. Analysis of the Suitability of High-Resolution DEM Obtained Using ALS and UAS (SfM) for the Identification of Changes and Monitoring the Development of Selected Geohazards in the Alpine Environment-A Case Study in High Tatras, Slovakia Remote sensing. 2020, 12(13), ISSN 2072-4292. Doi: $10.3390 / \mathrm{rs} 12233901$

Vařeka, P., 2020. Archeologie komunismu. Př́spěvek k odhalování represivních strategií totalitních režimů (in Czech, Archeology of communism. Contribution to the revelation of repressive strategies of totalitarian régimes). Dějiny a současnost .Vol 42, Nr. 4 (2020), pp. 38-42 